Gut, 1979, 20, 89-97

\title{
Pure pancreatic juice studies in normal subjects and patients with chronic pancreatitis
}

\author{
M. E. DENYER AND P. B. COTTON \\ From the Gastrointestinal Unit, The Middlesex Hospital, London
}

SUMMARY Pure pancreatic juice was obtained from within the pancreatic duct in 54 patients after endoscopic cannulation of the papilla of Vater. In all 20 normal subjects there was a brisk response to intravenous injections of GIH secretin in small dosage (1 and $4 \mathrm{CU}$ ). Peak bicarbonate concentrations occurred after a $4 \mathrm{CU}$ stimulus, whereas volumes, and bicarbonate and protein outputs were greatest after $70 \mathrm{CU}$. Total protein and amylase concentrations were highest in the first specimens collected from each patient, and fell rapidly after stimulation. Plateau levels for all indices were achieved 10-20 minutes after starting infusions of secretin and pancreozymin. When normal patients and those with chronic pancreatitis were compared, there was considerable overlap in all indices (volume, bicarbonate and total protein concentrations) after bolus injections of secretin. Most patients with chronic pancreatitis achieved a peak bicarbonate concentration in excess of $100 \mathrm{mmol} / \mathrm{l}$. The median concentrations were not significantly different from normal after any dose of secretin when pooled 10 minute samples were analysed. However there were significant differences in peak bicarbonate concentrations (after 1 and $4 \mathrm{CU}$, but not after $70 \mathrm{CU}$ ), when one minute samples were compared. There were also statistically significant differences in the median 10 minute responses for volume after 1 and $70 \mathrm{CU}$, for bicarbonate output after 1, 4, and $70 \mathrm{CU}$, and for protein output after $70 \mathrm{CU}$. The results of juice studies in patients believed to have early chronic pancreatitis did not differ significantly from those in normal subjects or those with chronic pancreatitis. Endoscopic duct cannulation cannot guarantee complete recovery of pancreatic secretions, and measurements of volume and output may be inaccurate. When standard biochemical indices are used, the diagnostic role of pure juice studies is limited; further research may reveal more specific disease markers.

Much of our knowledge of human pancreatic exocrine function has been derived from standard pancreatic function tests, which involve the collection of duodenal contents after hormone stimulation. However, recovery in such studies in unpredictable, and pancreatic juice is necessarily contaminated by bile and other secretions. The fibreoptic duodenoscope now allows deep cannulation of the papilla of Vater in conscious subjects. The technique has mainly been used for diagnostic retrograde cholangiography and pancreatography (Cotton, 1977) but also permits the collection of uncontaminated pancreatic juice (and bile) (Cotton et al., 1974). We have explored the pure pancreatic juice response to graded doses of secretin and pancreozymin in normal subjects and patients with pancreatitis.

Received for publication 1 September 1978

\section{Methods}

PATIENTS

Pure pancreatic juice (PPJ) collections were attempted in 68 patients who had been referred for investigation of known or suspected pancreatic disease. All patients had already undergone diagnostic endoscopic retrograde cholangiopancreatography (ERCP). Fifty-four collections were successful in 52 patients, but five patients were excluded from analysis because the final diagnosis was not clear at the end of the study. The remaining 47 patients have been divided into three groups: normal, chronic pancreatitis, and probable early chronic pancreatitis. The criteria used in classification are shown in Table 1. Among the 19 patients finally judged to have no pancreatic disease, four had peptic ulcers and two were shown to have gallstones. No 
Table 1 Diagnostic criteria used in classifying patients

\begin{tabular}{|c|c|c|c|c|c|c|c|}
\hline \multirow[t]{3}{*}{ Group } & \multirow[t]{3}{*}{ Number of patients } & \multicolumn{6}{|c|}{ Investigations performed } \\
\hline & & \multicolumn{3}{|c|}{$E R C P$} & \multirow[t]{2}{*}{ Standard PFT } & \multirow[t]{2}{*}{ Ultrasound } & \multirow[t]{2}{*}{ Laparotomy } \\
\hline & & $N$ & Equiv & $A b n$ & & & \\
\hline Normal pancreas & $\begin{array}{l}6 \\
5 \\
2 \\
2 \\
3 \\
1\end{array}$ & $\begin{array}{l}6 \\
5 \\
2 \\
2 \\
3\end{array}$ & 1 & & $\begin{array}{l}\mathbf{N} \\
\mathbf{N} \\
\mathbf{N}\end{array}$ & $\begin{array}{l}\mathbf{N} \\
\mathbf{N} \\
\mathbf{N}\end{array}$ & $\begin{array}{l}\mathbf{N} \\
\mathbf{N}\end{array}$ \\
\hline Total & 19 & 18 & 1 & & 9 & 6 & 3 \\
\hline ?Chronic pancreatitis & $\begin{array}{l}8 \\
5 \\
1\end{array}$ & $\begin{array}{l}1 \\
3 \\
1\end{array}$ & $\begin{array}{l}7 \\
2\end{array}$ & & $\begin{array}{l}\text { Equiv } \\
\text { Equiv }\end{array}$ & $\mathbf{N}$ & \\
\hline Total & 14 & 5 & 9 & & 6 & 1 & \\
\hline Chronic pancreatitis & $\begin{array}{l}2 \\
3 \\
1 \\
4 \\
2 \\
1 \\
1\end{array}$ & $\begin{array}{l}1 \\
2 \\
1\end{array}$ & 1 & $\begin{array}{l}1 \\
2 \\
1 \\
2 \\
2 \\
1\end{array}$ & $\begin{array}{l}\text { Abn } \\
\text { Ábn } \\
\text { Abn } \\
\text { Abn }\end{array}$ & $\begin{array}{l}\text { Abn } \\
\text { Abn } \\
\text { Abn }\end{array}$ & $\begin{array}{l}\mathrm{CP} \\
\mathrm{CP} \\
\mathrm{CP}\end{array}$ \\
\hline Total & 14 & 4 & 1 & 9 & 7 & 4 & 6 \\
\hline Grand totals & 47 & 27 & 11 & 9 & 22 & 11 & 9 \\
\hline
\end{tabular}

N: normal, Equiv: equivalent, abn: abnormal, CP: chronic pancreatitis; PFT: secretin-pancreozymin function test.

organic cause for the presenting symptoms was found in the remainder, and no evidence of pancreatic disease has become evident in a follow-up period of one to three years. The 14 patients classified as suffering from chronic pancreatitis all had evidence of irreversible pancreatic damage (Table 1). Only two patients showed calcification on plain radiographs, and none suffered from diabetes mellitus. The third and intermediate group of patients classified as ? early chronic pancreatitis consisted of 14 patients who had suffered recurrent attacks of pancreatic type pain for at least two years, but in whom standard investigations (Table 1) showed no clear-cut evidence of chronic pancreatitic damage. Eight of these patients had suffered well-documented attacks of acute pancreatitis (with serum amylase levels greater than three times the normal) on one or more occasions before the study (but not within two months of investigation).

PPJ collections were performed in a standard manner, with the patient lying in the left lateral semiprone position. All patients were starved overnight and sedated with intravenous injections of diazepam (Valium) in a dose of 5-20 mg. No anticholinergic agents were used. Cannulation was performed with a standard side-viewing duodenoscope and Teflon catheter $(1.6 \mathrm{~mm}$ external and $1 \mathrm{~mm}$ internal diameter) with a single end-hole. The catheter was primed with dilute indocyanine green to mark its dead space. Deep cannulation was judged to have been achieved when the catheter tip had passed more than $2 \mathrm{~cm}$ through the papilla. PPJ was collected by syphonage at $75 \mathrm{~cm}$ below the mouth, in one minute samples for up to one hour.

Purified porcine secretin and cholecystokininpancreozymin were obtained from the Gastrointestinal Hormone Laboratory, Karolinska Institute, Stockholm. Hormones were dissolved in a standard mixture of $16.5 \mathrm{ml} 0.9 \%$ saline, $1 \mathrm{ml}$ Trasylol for stabilisation and $2.5 \mathrm{ml}$ human serum albumin to prevent aggregation of molecules when using very small doses. Sufficient diluent was added to each ampoule of secretin or cholecystokinin-pancreozymin to provide a concentration of $10 \mathrm{CU} / \mathrm{ml}$. Individual doses were then withdrawn. A $1 \mathrm{ml}$ insulin syringe was used for small doses, which were further diluted to $5 \mathrm{ml}$ with the diluent. All doses were prepared immediately before injection.

Injections were given after a five minute basal collection period. The first 34 patients received bolus intravenous injections of secretin of increasing strength at 10 minute intervals $(1,4$ and $70 \mathrm{CU}$, approximating to $0.014,0.057$ and $1.0 \mathrm{CU} / \mathrm{kg}$ ). Nine patients also received an initial dose of 0.5 
CU (approximately $0.007 \mathrm{CU} / \mathrm{kg}$ ) and five patients were given an additional injection of the diluent solution alone during the sequence. In the remaining 15 studies, an initial bolus intravenous injection of 4 CU GIH secretin was followed after 10 minutes by an infusion of secretin plus cholecystokininpancreozymin (both $1 \mathrm{CU} / \mathrm{kg} /$ hour) for up to 40 minutes.

PPJ samples were collected over ice, frozen, and maintained at $-20^{\circ} \mathrm{C}$ before analysis. Volumes were measured by weighing; concentrations of sodium and potassium by flame photometry; chloride with a corning Eel chloride meter; bicarbonate by the method of Van Slyke using a Natelson microgasometer; total protein by a modified Lowry method (Huemer and Lee, 1970) and amylase activity by an iodometric method (Pimstone, 1965). Between batch coefficients of variation ranged from $0.5 \%$ for sodium to $6.3 \%$ for total protein, and the within batch coefficient of variation for amylase estimations was $11 \%$. In comparisons between groups of patients, the results were expressed for each 10 minute period in terms of volume, mean bicarbonate concentration, bicarbonate output, mean protein concentrations, amylase, and protein output. Since data were not normally distributed, statistical analyses were performed using the Wilcoxon Rank test.

\section{Results}

\section{NORMAL SUBJECTS}

\section{Bolus injections}

A brisk flow of juice followed within minutes of the intravenous injection of secretin in all patients, even at the lowest doses (Figs 1 and 7). The response increased in size and duration with increasing doses. Within individuals, the sodium and potassium concentrations remained almost constant throughout the studies, whereas the bicarbonate and chloride concentrations closely approximated to the sum of the sodium and potassium concentrations (Fig. 2). Bicarbonate concentration rose less rapidly than the volume after the initial stimulus, but this partly reflects the deadspace of the catheter. In most normal subjects the peak concentration was achieved after $4 \mathrm{CU}$, and was lower after $70 \mathrm{CU}$ (Figs 3 and 8). The bicarbonate output, however, rose progressively with increasing stimulation (Figs 4 and 10). In normal subjects the highest total protein concentrations were seen in the first specimens collected (Fig. 5), with a rapid fall to a plateau as stimulation continued. Each secretin injection, however, resulted in a transient but marked rise in protein concentration (Fig. 5). Amylase and protein concentrations were significantly correlated $\left(r_{s}=0.88, n=98\right.$, $P<0.00001$ ). Ten minute protein outputs rose progressively after each stimulus.

\section{Infusions}

Volume response to secretin-cholecystokinin-pancreozymin infusion reached a plateau (of approximately $4 \mathrm{ml} / \mathrm{min}$ ) after $20-30$ minutes, but there was a tendency for bicarbonate concentrations to fall later (Fig. 6). The total protein concentration fell to a constant level over the same period. The plateau value for each index was similar to that

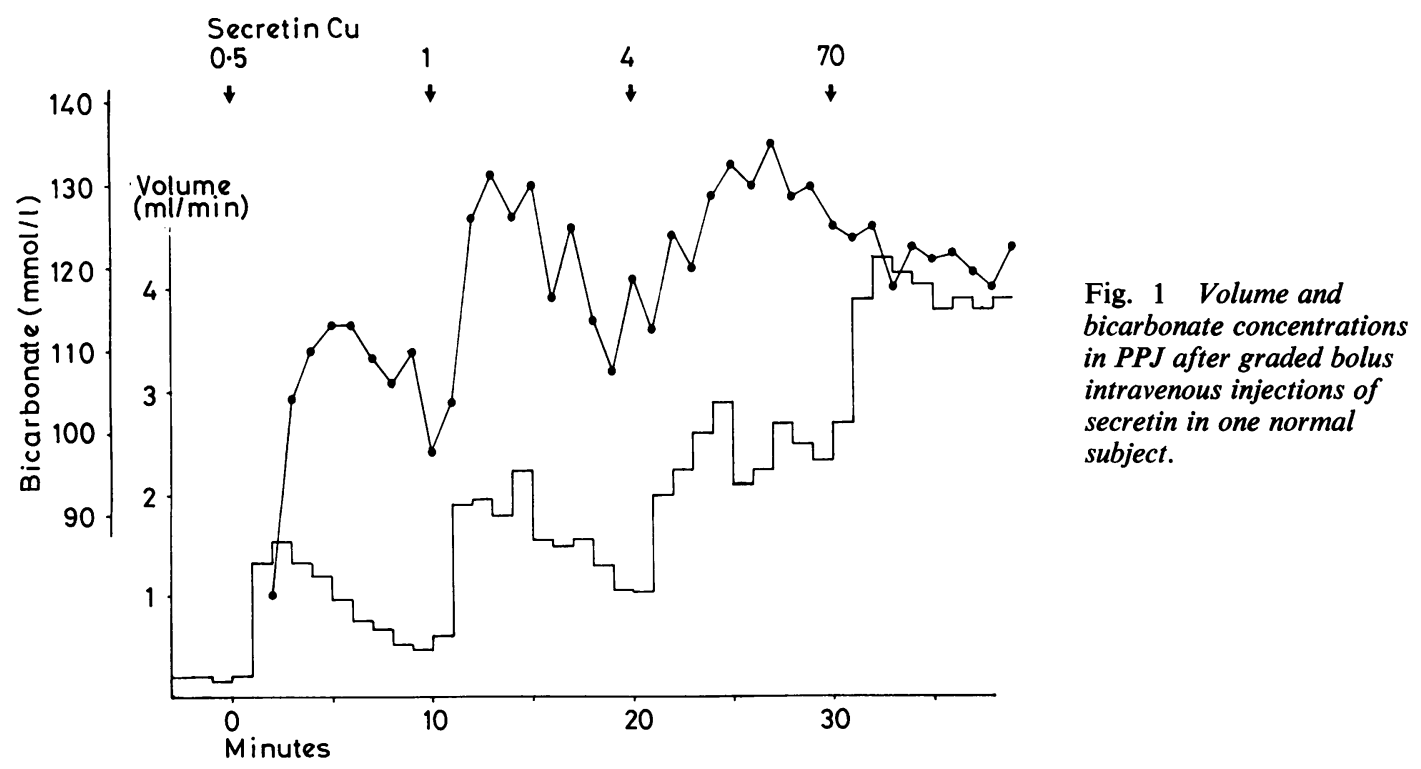




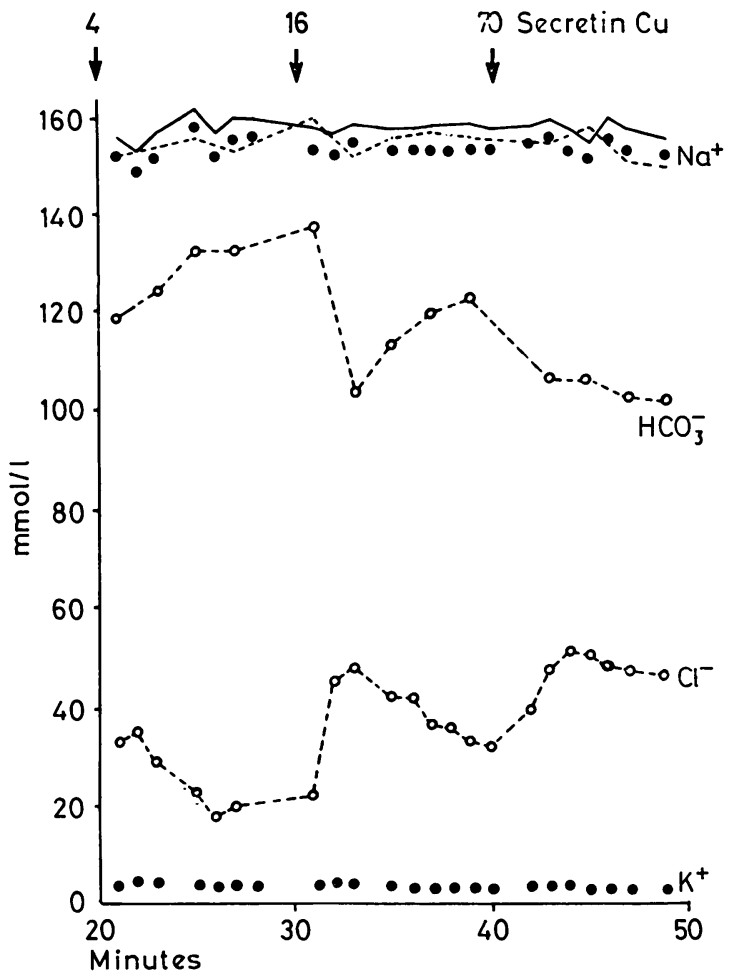

Fig. 2 Electrolyte changes in one normal subject after increasing doses of secretin. The sums of the cations, (solid line) and anions (dashed line) are similar, at the top of the graph.

seen after the $70 \mathrm{CU}$ bolus injections in other normal subjects (Fig. 7).

\section{PATIENTS WITH CHRONIC PANCREATITIS AND? EARLY CHRONIC PANCREATITIS}

\section{Bolus injections}

There was considerable overlap in the response of these two groups of patients when compared with the normal subjects, in terms of volume (Fig. 7), 10 minute bicarbonate concentration (Fig. 8), and bicarbonate output (Fig. 10). Statistically significant differences were found between normal subjects and those with established chronic pancreatitis for volume after 1 and $70 \mathrm{CU}$, for 10 minute bicarbonate concentration only after $4 \mathrm{CU}$, and for bicarbonate output after all stimuli (Table 2). When one minute peaks of bicarbonate concentration were compared, however, significant differences were found between normal subjects and patients with chronic pancreatitis after 1 and $4 \mathrm{CU}$ doses of secretin (Fig. 9). In patients with chronic pancreatitis the protein concentration in the first juice collected (after l CU)

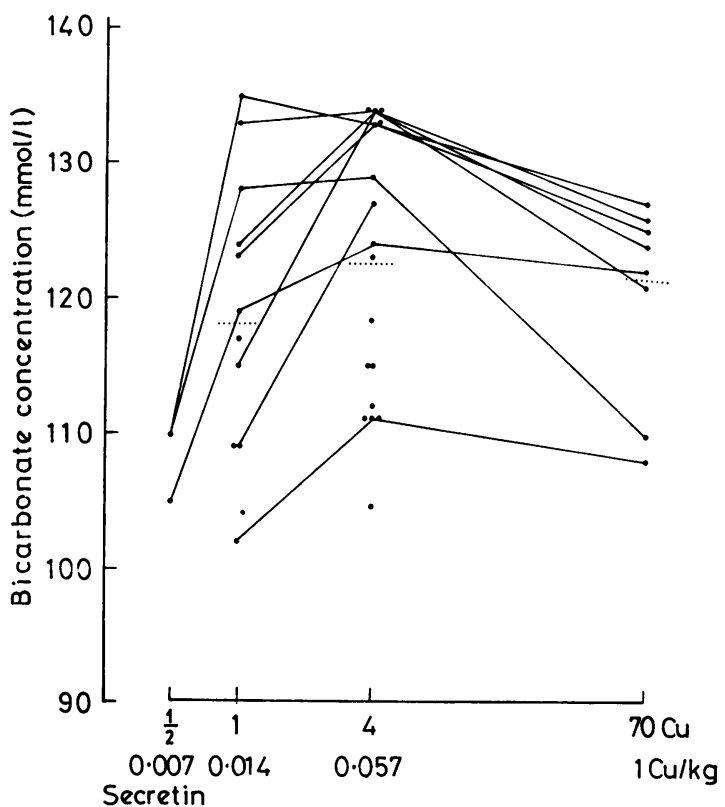

Fig. 3 Bicarbonate concentrations in all normal subjects after graded bolus intravenous injections of secretin. The median values are shown by dotted lines. The median values between 1 and $4 C U$, and between 4 and $70 C U$ are significantly different $(\mathrm{P}<0 \cdot 05)$.

appeared higher than in normal subjects, but the differences did not reach statistical significance (Table 2); the protein output was significantly less after $70 \mathrm{CU}$ among patients with chronic pancreatitis. No significant difference for any index was seen between normal subjects and those with probable early chronic pancreatitis, nor between the latter and those with established chronic pancreatitis.

\section{Infusions}

The numbers in the three groups of patients were small, therefore no statistical comparison could be made. There was a tendancy for volume, bicarbonate output, and protein output to be higher in normal subjects than in those with chronic pancreatitis (Table 3) but no other obvious difference was observed.

\section{Discussion}

Human pure pancreatic juice studies are technically demanding, and few results have been published. Our studies provide some base line information about the response of the normal pancreas to secretin, and the results with very small doses $(0.5$ and $1 \mathrm{CU})$ are particularly interesting. When 
(8.27)

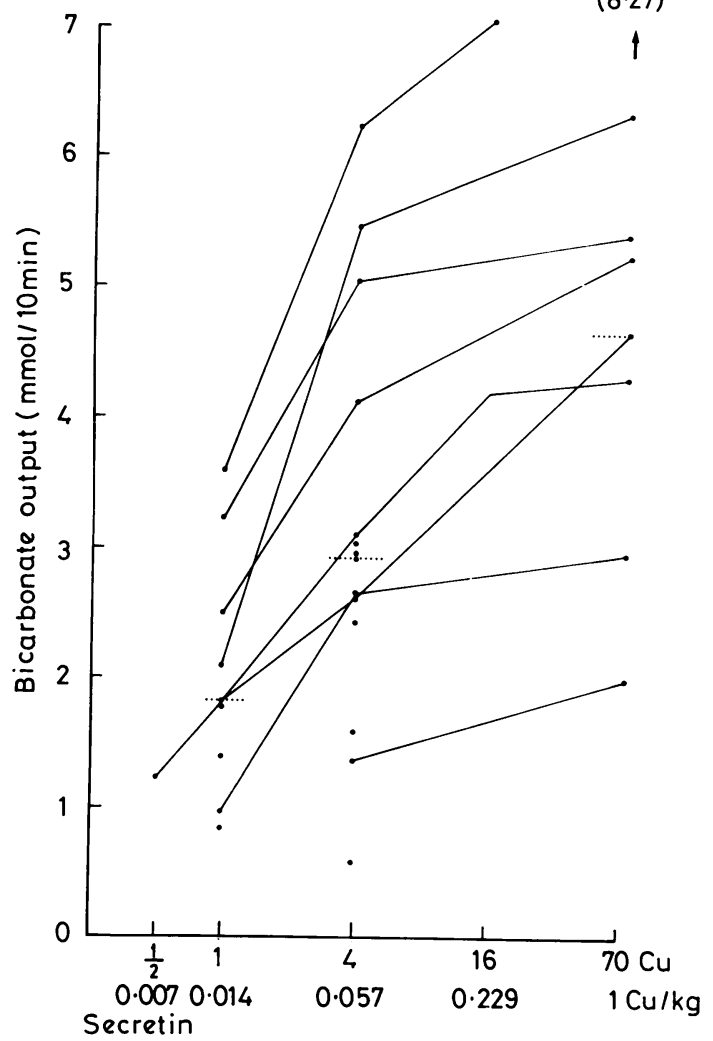

Fig. 4 Bicarbonate outputs in all normal subjects after graded bolus intravenous injections of secretin. given by slow intravenous infusion, these doses cause rises in serum levels in immunoreactive secretin, comparable with those achieved by endogenous release after intraduodenal infusion of acid (Ward and Bloom, 1974); this suggests that they are within the physiological range. Similar pure juice responses were reported by Domschke et al. (1976) using low dose secretin infusion.

The volume response to $70 \mathrm{CU}$ (roughly $1 \mathrm{CU} / \mathrm{kg}$ ) in our normal subjects was similar to that reported by Gregg and Sharma (1975) using Boots secretin but greater than that recorded by Kawanishi et al. (1975a). The finding of a higher bicarbonate concentration after $4 \mathrm{CU}$ than after $70 \mathrm{CU}$ accords with the findings of Domschke et al. (1976), and early work on duodenal juice (Wormsley, 1968).

To clinicians, lack of convincing differences between normal subjects and patients with chronic pancreatitis will be surprising and disappointing. There was considerable overlap in all the measured indices.

Only two patients with chronic pancreatitis failed to achieve a bicarbonate concentration higher than $90 \mathrm{mmol} / \mathrm{l}$, the commonly accepted criterion for abnormality in standard duodenal drainage function tests. This suggests that the much lower figures normally reported in duodenal juice result from the dilution of smaller quantities of pancreatic juice within the duodenum by bile and other intestinal contaminants. The differences also reflect the selection of patients. Many studies of pancreatic function in chronic pancreatitis contain a high proportion with calcification of the gland on

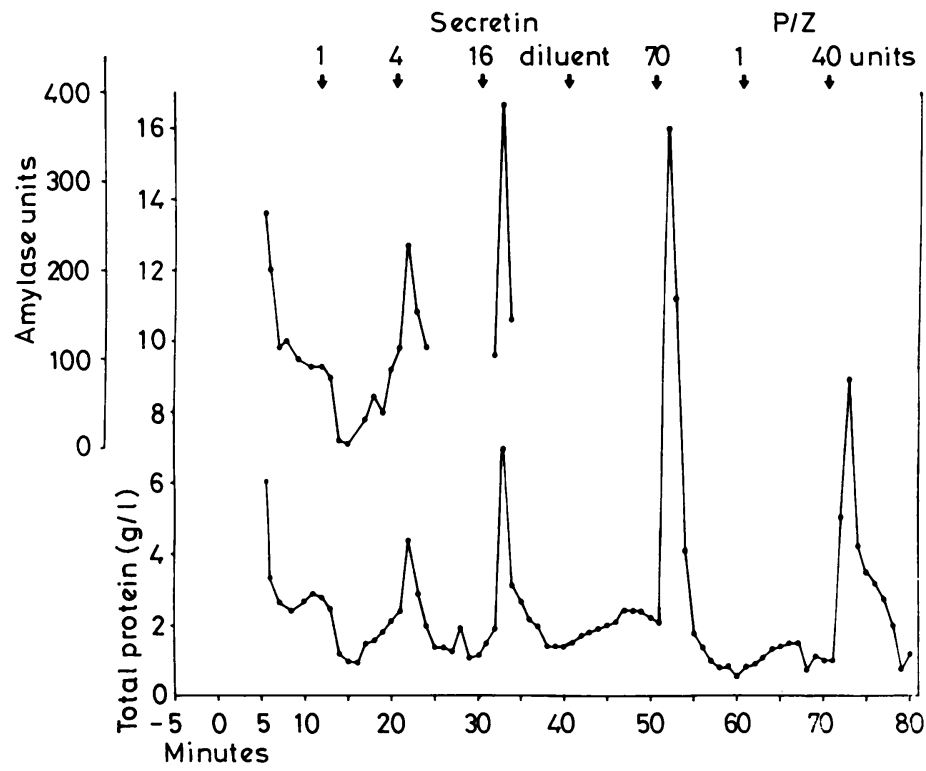

Fig. 5 Total protein and amylase concentrations in one normal subject after graded bolus intravenous injections of secretin, and cholecystokinin-pancreozymin $(P / Z)$. 


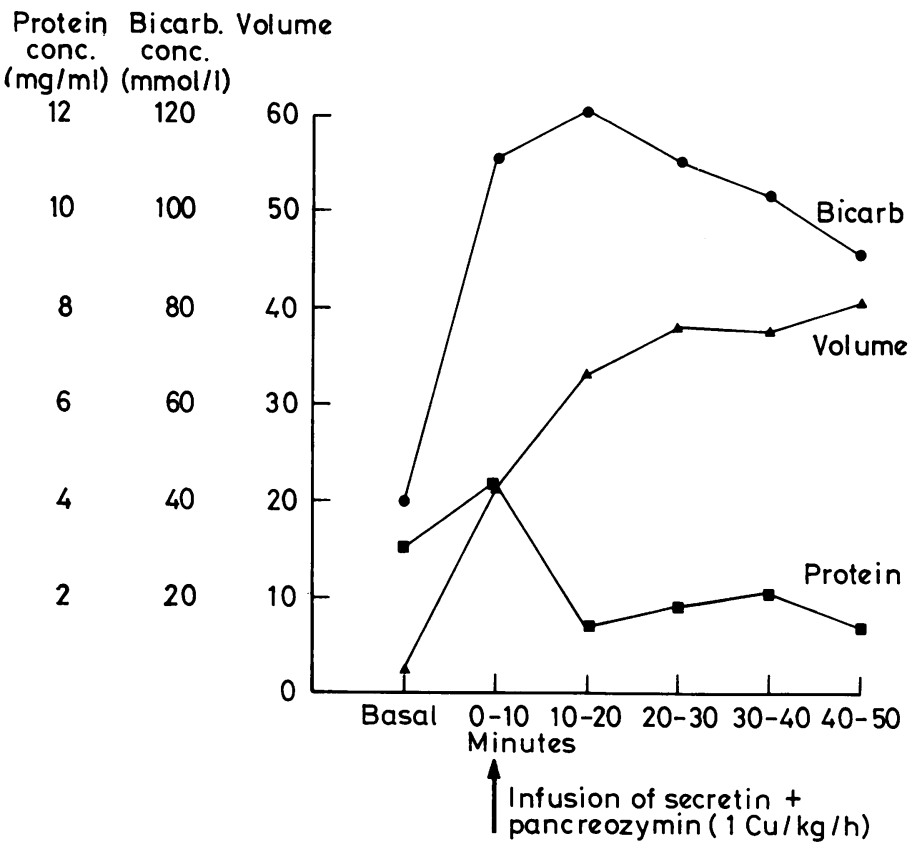

Fig. 6 Median volume, bicarbonate concentration and protein concentration in all normal subjects after the infusion of secretin and cholecystokininpancreozymin (each one $\mathrm{CU} / \mathrm{kg} / \mathrm{h}$ ).

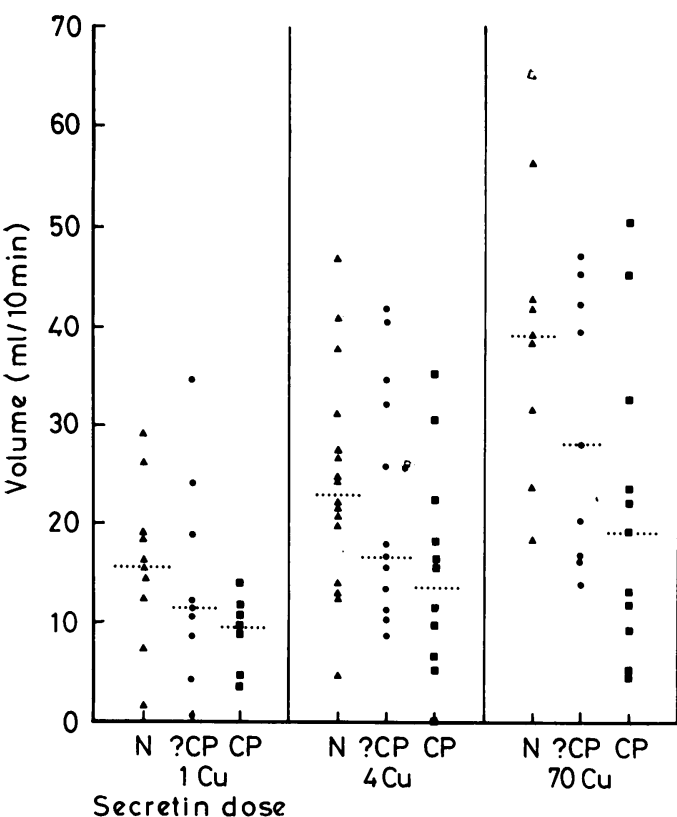

Fig. 7 Median 10 minute volume responses in all patients after bolus injections of secretin (median levels shown by dotted line: $N$ : normal, $C P$ : chronic pancreatitis, ?CP: probable early pancreatitis).

plain radiographs. This provides a convenient and definite diagnostic end-point, but is applicable only to the most severe cases. Only two of our patients

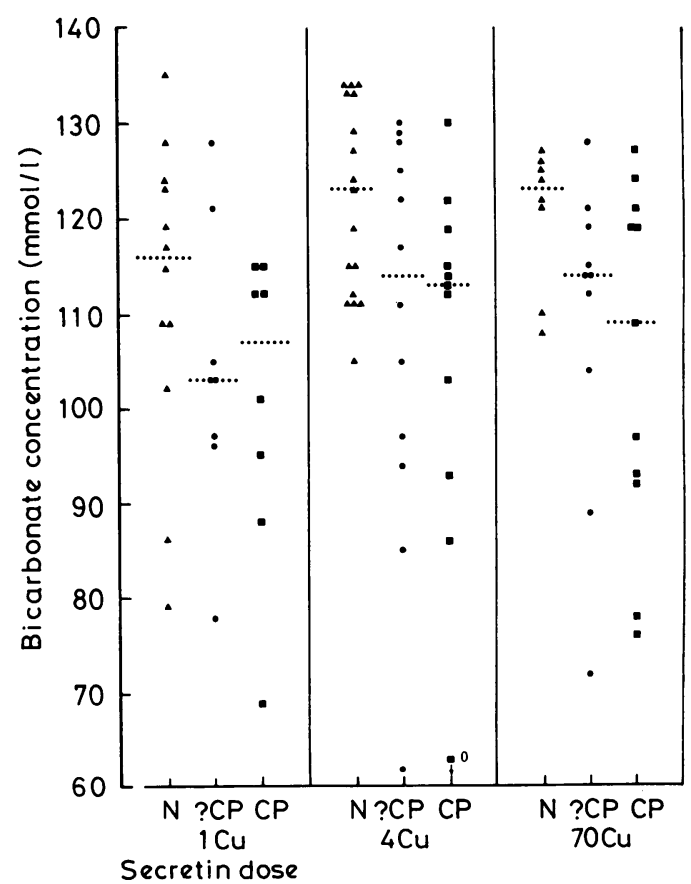

Fig. 8 Median 10 minute bicarbonate concentrations in all patients after graded bolus intravenous injections of secretin. 
Table 2 Differences between normal subjects and chronic pancreatitis after bolus injections of secretin

\begin{tabular}{|c|c|c|c|c|c|c|c|c|c|c|c|}
\hline $\begin{array}{l}\text { Secretin } \\
\text { dose }(C U)\end{array}$ & Group & $\begin{array}{l}\text { Volume } \\
(\mathrm{ml} / 10 \mathrm{~min})\end{array}$ & $\mathbf{P}$ & $\begin{array}{l}\text { Bicarb conc. } \\
(\text { mmollt })\end{array}$ & $\mathbf{P}$ & $\begin{array}{l}\text { Bicarb output } \\
(\mathrm{mmol} / 10 \mathrm{~min})\end{array}$ & P & $\begin{array}{l}\text { Protein conc. } \\
(\mathrm{mg} / \mathrm{ml})\end{array}$ & $\mathbf{P}$ & $\begin{array}{l}\text { Protein output } \\
(\mathrm{mg} / 10 \mathrm{~min})\end{array}$ & $\mathbf{P}$ \\
\hline 1 & $\begin{array}{l}\mathrm{N} \\
\mathrm{CP}\end{array}$ & $\begin{array}{l}\mathrm{m}=15 \cdot 75 \\
\mathrm{n}=12 \\
\mathrm{~m}=9 \cdot 3 \\
\mathrm{n}=8\end{array}$ & $<0.05$ & $\begin{array}{l}\mathrm{m}=116 \\
\mathrm{n}=12 \\
\mathrm{~m}=107 \\
\mathrm{n}=8\end{array}$ & NS & $\begin{array}{l}\mathrm{m}=1.82 \\
\mathrm{n}=10 \\
\mathrm{~m}=1.0 \\
\mathrm{n}=8\end{array}$ & $<0.01$ & $\begin{array}{l}\mathrm{m}=2 \cdot 8 \\
\mathrm{n}=9 \\
\mathrm{~m}=9 \cdot 8 \\
\mathrm{n}=7\end{array}$ & NS & $\begin{array}{l}m=49 \cdot 5 \\
n=8 \\
m=44 \cdot 6 \\
n=7\end{array}$ & NS \\
\hline 4 & $\begin{array}{l}\mathrm{N} \\
\mathrm{CP}\end{array}$ & $\begin{array}{l}\mathrm{m}=22 \cdot 8 \\
\mathrm{n}=18 \\
\mathrm{~m}=13 \cdot 4 \\
\mathrm{n}=12\end{array}$ & NS & $\begin{array}{l}m=123 \\
n=17 \\
m=113 \\
n=11\end{array}$ & $<0.05$ & $\begin{array}{l}\mathrm{m}=2.92 \\
\mathrm{n}=13 \\
\mathrm{~m}=1.74 \\
\mathrm{n}=10\end{array}$ & $<0.05$ & $\begin{array}{l}m=1 \cdot 8 \\
n=16 \\
m=2 \cdot 6 \\
n=11\end{array}$ & NS & $\begin{array}{l}\mathrm{m}=35 \cdot 8 \\
\mathrm{n}=16 \\
\mathrm{~m}=26 \cdot 3 \\
\mathrm{n}=11\end{array}$ & NS \\
\hline 70 & $\begin{array}{l}\mathrm{N} \\
\mathrm{CP}\end{array}$ & $\begin{array}{l}m=39 \cdot 2 \\
n=9 \\
m=19 \cdot 2 \\
n=11\end{array}$ & $<0.05$ & $\begin{array}{l}m=123 \\
n=8 \\
m=109 \\
n=11\end{array}$ & NS & $\begin{array}{l}m=4.95 \\
n=8 \\
m=1.75 \\
n=11\end{array}$ & $<0.05$ & $\begin{array}{l}\mathrm{m}=1.8 \\
\mathrm{n}=8 \\
\mathrm{~m}=1.6 \\
\mathrm{n}=11\end{array}$ & NS & $\begin{array}{l}\mathrm{m}=87 \cdot 4 \\
\mathrm{n}=8 \\
\mathrm{~m}=27 \cdot 1 \\
\mathrm{n}=11\end{array}$ & $<0.05$ \\
\hline
\end{tabular}

$\mathrm{N}$ : normal; CP: chronic pancreatitis; $\mathrm{m}$ : median value; $\mathrm{n}$ : number of patients.

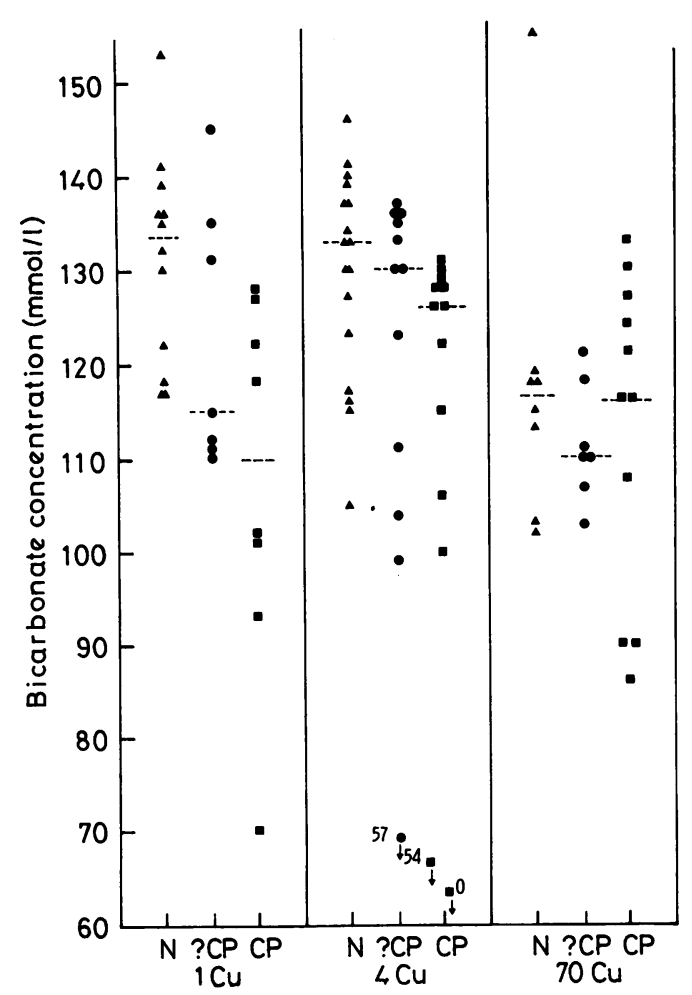

Secretin dose

Fig. 9 Peak bicarbonate concentrations in one minute specimens in all patients after graded bolus injections of secretin. There are significant differences between normal subjects and $C P$ after $1 C U(\mathrm{P}<0.01)$ and $4 C U$ $(\mathrm{P}<0.02)$. No differences were seen between normal patients and those with? early chronic pancreatitis at any dose.

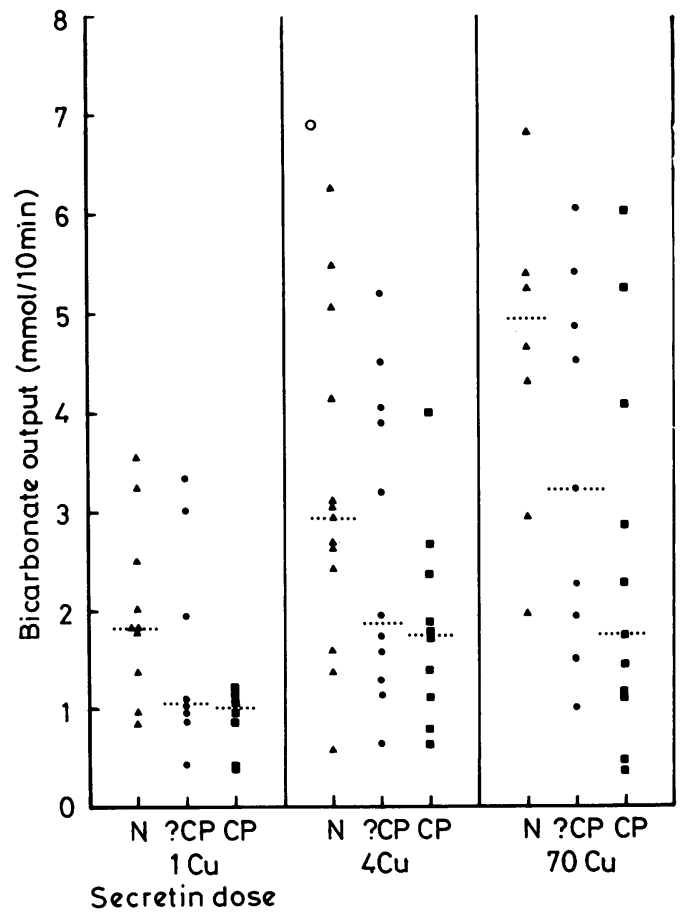

Fig. 10 Ten minute bicarbonate outputs in all patients after graded bolus injections of secretin.

showed calcification; in one patient there was no flow of pancreatic juice at all after deep cannulation and secretin stimulation. Patients with calcifying chronic pancreatitis do not require a further diagnostic test-the diagnosis is already established. The diagnostic problem occurs in less severe cases and the main purpose of this study was to see whether 
Table 3 Median values ( + ranges) in the groups of patients in 10 minute period starting 20 minutes after start of secretin-cholecystokinin-pancreozymin infusion

\begin{tabular}{lccc}
\hline & Normal & $? C P$ & $C P$ \\
\hline Total patients & 7 & 4 & 3 \\
Volume (ml/10 min) & $37 \cdot 5$ & $26 \cdot 5$ & $20 \cdot 5$ \\
& $(29 \cdot 3-53 \cdot 9)$ & $(21 \cdot 8-39 \cdot 8)$ & $(0-35 \cdot 9)$ \\
Bicarbonate concn (mmol/1) & 103 & 115 & 105 \\
& $(84-121)$ & $(101-116)$ & $(0-125)$ \\
Output (mmol/10 min) & $3 \cdot 75$ & $2 \cdot 85$ & $2 \cdot 65$ \\
& $(3 \cdot 1-4 \cdot 55)$ & $(2 \cdot 55-4 \cdot 6)$ & $(0-4 \cdot 35)$ \\
Protein concn (mg/ml) & $1 \cdot 85$ & $1 \cdot 75$ & $1 \cdot 9$ \\
& $(0 \cdot 7-3 \cdot 2)$ & $(0 \cdot 8-5 \cdot 6)$ & $(0-3 \cdot 3)$ \\
Output (mg/ 10 min) & 70 & 47 & 33 \\
& $(46-93)$ & $(31-122)$ & $(0-78)$ \\
\hline
\end{tabular}

pure pancreatic juice function testing provided better discrimination. This was the reason for studying less severe, but definite, chronic pancreatitis, and also a group with probable chronic pancreatitis at an even earlier stage.

In the pure juice studies, the functional defect in patients with chronic pancreatitis was more in volume production rather than bicarbonate concentrating ability. Thus the diagnostic capabilities of PPJ studies depend upon achieving complete recovery of the secreted juice; while this is likely with low flow rates, collections are certainly incomplete after higher doses of stimulants.

Even if it were proved safe to occlude the pancreatic duct orifice with a balloon catheter, some juice could escape in many patients through Santorini's duct and the accessory papilla. Furthermore, the resistance to flow down the long thin catheter might itself exert an influence upon the pancreatic response. It is difficult to measure the recovery fraction during pure juice studies, but this and other technical aspects are being examined. Some idea of recovery can be gained by comparing the results of pure juice studies with those of standard duodenal aspiration studies in the same patients. In our own comparison in 13 patients, the volumes obtained from the duodenum (uncorrected for recovery of markers) exceeded those obtained from the pancreatic duct in a ratio of $1 \cdot 1$ to 1 . After correction for duodenal recovery, the ratio was $2 \cdot 3$ to 1 . Some of this excess was due to secretions other than pancreatic juice, as evidenced by the fact that the mean bicarbonate concentration in pure juice exceeded that of duodenal juice by a mean of 30 $\mathrm{mmol} / \mathrm{l}$ (Denyer et al., 1977). Like Escourrou et al. (1978), we found that the bicarbonate output as measured in pure juice considerably exceeded that in duodenal aspirates in paired studies.

Total protein concentrations in these studies correlated very closely with amylase levels. The finding of high protein concentrations in the first juice specimens, and transient increases after each secretin stimulus are open to various explanations. It has been suggested that patients with chronic pancreatitis have high juice protein concentrations, leading to deposition of protein plugs, duct obtruction, and local calcification. A tendency towards higher protein concentrations was seen in our studies after low (physiological) doses of secretin, but did not reach statistical significance (Table 3).

Detailed analysis of individual enzymes and protein fractions in pure juice is technically complex. We were surprised to find active trypsin in the juice of some patients; protein fractions degraded rapidly even on freezing. Statements about protein constituents in pure juice can be accepted only if restricted to studies in which juice was shown not to contain active trypsin immediately on withdrawal. When these problems are overcome, pure juice studies should provide an ideal avenue for further detailed research into constituents which may have diagnostic significance, such as lactoferrin (Colomb et al., 1974; Fedail et al., 1978), carcinoembryonic antigen (Kawanishi et al., 1975b), isoamylases (Skude and Ihre, 1977), various protein fractions (Colomb et al., 1974; Allan and White, 1975), and gamma glutamyl transpeptidase (Renner and Juttner, 1976).

Pure juice studies are technically too difficult for routine clinical practice, but the results obtained can demonstrate the reliance to be placed upon simpler methods, and lead the search for more specific diagnostic markers.

The authors gratefully acknowledge the help gven in various parts of these studies by Dr A. Miller, Stephanie Tough, Cathryn Corns, Jean Townson, and Maria Kyne(Courtauld Institute of Biochemistry, The Middlesex Hospital and Medical School) and by Dr A. Reuben, Dr R. Stern, and Dr T. R. Heap. The research was generously supported by the Wellcome Trust, the North West Thames Regional Health Authority, and the Special Trustees of The Middlesex Hospital.

\section{References}

Allen, B. J., and White, T. T. (1975). A refined cellulose acetate-electrophoretic technique for analysis of human pancreatic juice. Biochemical Medicine, 12, 166-182.

Colomb, E., Estevenon, J. P., Figarella, C., Guy, O., and Sarles, H. (1974). Characterisation of an additional protein in pancreatic juice of men with chronic calcifying pancreatitis. Biochimica et Biophysica Acta, 342, 306-312. Cotton, P. B. (1977). ERCP. Gut, 18, 316-341.

Cotton, P. B., Cremer, M., Robberecht, P., Deltenre, M., Ponder, B., and Christophe, J. (1974). Pure pancreatic secretion collected from within the pancreatic duct at duodenoscopy. Preliminary results of biochemical studies (abstract). Gastroenterology, 66, 678.

Denyer, M. E., Cotton, P. B., Kyne, M., and Miller, A. 
(1977). Paired pancreatic function studies using pure pancreatic juice and duodenal juice. (Abstract). Gut, 18, A980.

Domschke, S., Domschke, W., Rösch, W., Konturek, S. J., Wünsch, E., and Demling, L. (1976). Bicarbonate and cyclic AMP content of pure human pancreatic juice in response to graded doses of synthetic secretin. Gastroenterology, 70, 533-536.

Escourrou, J., Frexinos, J., and Ribet, A. (1978). Biochemical studies of pancreatic juice collected by duodenal aspiration and endoscopic cannulation of the main pancreatic duct. American Journal of Digestive Diseases, 23, 173-177.

Fedail, S. S., Salmon, P. R., Harvey, R. F., and Read, A. E. (1978). Radioimmunoassay of lactoferrin in pancreatic juice as a test for pancreatic diseases. Lancet, 1, 181-182.

Gregg, J. A., and Sharma, M. M. (1976). The effect of secretin on pancreatic juice flow rates during endoscopic cannulation of the main pancreatic duct. (Abstract). Gastroenterology, 68, 905.

Huemer, R. P., and Lee, K. D. (1970). Automated Lowry method for microgram protein determination. Analytical Biochemistry, 37, 149-153.
Kawanishi, H., Sell, J. E., and Pollard, H. M. (1975a). Combined endoscopic pancreatic fluid collection and retrograde pancreatography in the diagnosis of pancreatic cancer and chronic pancreatitis. Gastrointestinal Endoscopy, 22, 82-85.

Kawanishi, H., Sell, J. E., and Pollard, H. M. (1975b). Carcinoembryonic antigen and cytology of pancreatic fluid. (Abstract). Gastroenterology, 66, 923.

Pimstone, N. R. (1965). A study of the starch-iodine complex: A modified colorimetric micro determination of amylase in biologic fluids. Clinical Chemistry, 10, 891-906.

Renner, I. G., and Juttner, H. U. (1976). A new non-specific marker of early pancreatic disease. (Abstract). Gastroenterology, 70, 929.

Skude, G., and Ihre, T. (1977). Isoamylases in pancreatic carcinoma and chronic relapsing pancreatitis. Scandinavian Journal of Gastroenterology, 12, 53-58.

Ward, A. S., and Bloom, S. R. (1974). The role of secretin in the inhibition of gastric secretin by intraduodenal acid. Gut, 15, 889-897.

Wormsley, K. G. (1968). Response to secretin in man. Gastroenterology, 54, 197-209. 